\title{
Upaya Meningkatkan Motivasi Dan Hasil Belajar Matematika Peserta didik Kelas V SD Negeri 38 Ampenan Semester Satu Tahun Pelajaran 2018/2019 Melalui Penerapan Pendekatan Cooperative Learning (CL) Tipe STAD
}

\author{
Hj. Hanifah, S.Pd \\ Guru Matematika SD Negeri 38 Ampenan
}

\begin{abstract}
Penelitian ini bertujuan untuk mengetahui efektifitas penerapan pendekatan cooperative learning (CL) tipe STAD dalam upaya meningkatkan motivasi belajar matematika siswa Kelas VI SD Negeri 38 Ampenan. Manfaat penelitian ini adalah sebagai bahan kajian dan bahan temuan dalam pelaksanaan proses pembelajaran di kelas senyatanya. Bagi guru untuk meningkatkan kompetensi dalam proses pembelajaran dan bagi siswa untuk meningktakan motivasi belajar yang berdampak meningkatnya hasil belajar siswa. Penelitian ini dilaksanakan dua siklus, masing-masing siklus kegiatannya adalah; perencanaan, pelaksanaan, observasi dan refleksi. Hasil akhir tindakan pada siklus II menunjukkan bahwa hasil observasi guru memperoleh skor rata-rata $(4,54)$ dan hasil observasi siswa mencapai skor rata-rata $(4,37)$. Sedangkan dampak dari peningkatan motivasi belajar adalah meningkatnya perolehan hasil belajar siswa mencapai nilai rata-rata $(79,00)$, artinya indikator keberhasilan $(\geq 4,0)$ telah terlampaui. Karena indicator keberhasilan telah terbukti penelitian dinyatakan berhasil dan dihentikan pada siklus II.
\end{abstract}

Kata Kunci : Motivasi dan Hasil Belajar - Pendekatan CL tipe STAD.

\section{PENDAHULUAN}

Upaya memandirikan peserta didik untuk belajar, bekerjasama, dan menilai diri sendiri diutamakan agar peserta didik mampu membangun kemauan, pemahaman, dan pengetahuan.Peningkatan potensi, kecerdasan, dan minat peserta didik perlu terus menerus di upayakan (Depdiknas, 2004; 3).Upaya yang konkrit yang dapat diwujudkan adalah menciptakan pembelajaran yang aktif, kreatif, efektif dan menyenangkan.

Kondisi sebagaimana yang dipaparkan diatas, sama yang dialami oleh kebanyakan peserta didikKelas VSD Negeri 38 Ampenan, selama proses pembelajaran peserta didik cenderung pasif, ketika guru bertanya tidak ada yang berani menjawab, ketika guru meminta peserta didik untuk menanyakan halhal yang belum tau/belum jelas semua diam, ketika guru menjelasskan materi pelajaran, ada yang tidur, ada yang main-main, ada pula yang SMS-an, ada yang saling lempar kertas, bermain cinta. Kondisi yang paling parah adalah ketika diberi tugas untuk mengerjakan soal banyak yang cuek.

Faktor penyebab kondisi diatas adalah kurang termotivasinya peserta didik dalam proses pembelajaran di kelas senyatanya, yang di picu dari model pembelajaran yang diterapkan oleh guru cenderung mengarak keguru aktif bukan peserta didik aktif. Peserta didik sebagai objek pembelajaran bukan sebagai subjek pembelajaran.Peserta didik menerima teori bukan menentukan teori.Peserta didik cenderung menghafal dari apa yang diberikan oleh guru bukan sebuah gagasan yang muncul dari keaktifan peserta didik selama proses pembelajaran. Materi pembelajaran cenderung mengarah pada ke kognitif bukan afektif atau psikomotorik.Peserta didik menerima bahan jadi bukan proses belajar pemecahan masalah (problem solving learning), peserta didik mendapat materi seutuhnya dari guru bukan hasil dari proses "Discoveri Inguiry".

Banyak solusi yang dapat dilakukan guna mengatasi permasalahan kurang termotivasinya belajar Matematikapeserta didikKelas VSD Negeri 38 Ampenan yaitu dengan menerapkan pendekatan pembelajaran Cooperative Learning (CL).Model pembelajaran ini peserta didik belajar dengan membentuk kelompok kecil.Di dalam kelompok itu peserta didik dapat saling asah, saling asuh dalam memecahkan permasalahan yang diberikan oleh guru.Pendekatan Cooperative Learning banyak macamnya, diantaranya adalah model pembelajaran tipe 
STAD (Student Teams Archivement Divisions). Model pembelajaran tipe STAD ini terdiri dari lima komponen utama, yaitu, presentasi kelas, tim, kuis, skor kemajuan individu dan rekognisi tim. Dengan model pembelajaran tipe STAD diharapkan motivasi dan hasil belajar dari peserta didikKelas $\mathrm{V}$ di SD Negeri 38 Ampenan dapat ditingkatkan.

Untuk membuktikan pernyataan diatas, maka perlu diadakan penelitian tindakan kelas (PTK) dengan menerapkan Cooperative Learning (CL) tipe STAD dalam upaya meningkatkan motivasi dan hasil belajarMatematikapeserta didikKelas VSD Negeri 38 AmpenanSemester satuTahun Pelajaran 2018/2019. Sehubungan dengan itu maka penelitian tindakan kelas (PTK) ini berjudul "Upaya Meningkatkan Motivasi Dan Hasil Belajar MatematikaPeserta didikKelas VSD Negeri 38 Ampenan Semester Satu Tahun Pelajaran 2018/2019 Melalui Penerapan Pendekatan Cooperative Learning (CL) Tipe STAD”.

\section{Rumusan Masalah}

"Apakah penerapan pendekatan Cooperative Learning (CL) tipe STAD dapat meningkatkan motivasi dan hasil belajarMatematikapeserta didikKelas VSD Negeri 38 AmpenanSemester satuTahun Pelajaran 2018/2019.

\section{Tujuan penelitian}

1. Untuk mengetahui sejauh mana efektivitas penerapan model pembelajaran tipe STAD dalam upaya meningkatkan motivasi dan hasil belajar Matematikapeserta didikKelas VSD Negeri 38 Ampenan.

2. Untuk mengetahui peningkatan motivasi dan hasil belajar peserta didikKelas VSD Negeri 38 AmpenanTahun Pelajaran 2018/2019 sebagai dampak dari penerapan model pembelajaran CL tipe STAD.

\section{Manfaat Penelitian}

- Bermanfaat bagi guru selaku peneliti dalam rangka melaksanakan proses pembelajaran yang kontekstual melalu penerapan model pembelajaran Cooperative Learning (CL) tipe STAD di kelas senyatanya serta dalam upaya perwujudan pembelajaran yang aktif, inovatif, kreatif, efektif, dan menyenangkan (PAIKEM) sehingga motivasi peserta didik dapat ditingkatkan.

- Bagi peserta didik sangat bermanfaat dalam upaya peningkatan motivasi dan hasil belajar yang berdampak meningkatnya prestasi belajar peserta didik.

\section{KAJIAN PUSTAKA \\ Motivasi}

Motivasi dapat diartikan serangkaian usaha menyediakan kondisi-kondisi tertentu, sehingga seorang itu mau dan ingin melakukan sesuatu dan bila ia tidak suka, maka akan berusaha meniadakan dan meyalahkan perasaan tidak suka itu (Sardiman, 2007). Pendapat lain mengatakan bahwa motivasi dan hasil belajar adalah merupakan faktor fisik yang bersifat non intelektual (Hil,2002). Peserta didik yang memiliki motivasi yang kuat, akan mempunyai banyak energy untuk melakukan kegiatan (Sardiman, 2007). Jika guru memiliki suatu kejelasan ide mengenai arah program pembelajaran peserta didik dapat diberi kebebasan untuk menyesuaikan bahan dan program tersebut pada suatu arah dan konteks dari pilihannya sendiri (Nurhaadi, 2003). Jika peserta didik berpartisipasi dalam pembuatan perencanaan pengalaman belajarnya sendiri, motivasi peserta didikakan meningkat dan terjaga dengan baik.

Dalam penelitian ini, motivasi dan hasil belajar yang akan diukur adalah pola belajar peserta didik dalam proses pembelajaran Matematika di kelas yaitu sikap antusias terhadap materi yang diajarkan. Prilaku untuk anak bekerjasama dalam kelompok kecil, keaktifan dalam melaksanakan kerjasama dalam kelompok, kemampuan tiap-tiap peserta didik untuk menjawab pertanyaan dari teman sejawat maupun yang berasal dari guru mata pelajaran, dan yang terakhir adalah kemampuan peserta didik untuk memanage waktu yang diberikan oleh guru untuk masing-masing kelompok,

\section{Hasil belajar}

Mukhtar (2003:54) mengatakan bahwa pengertian hasil belajar tidak dapat dipisahkan dan apa yang terjadi dalam aktifitas pembelajaran baik di kelas maupun diluar 
kelas. Apa yang dialami oleh peserta didik dalam proses pengembangan kemampuannya merupakan apa yang diperoleh dalam belajar dan pengalaman tersebut pada akhirnya dipengaruhi oleh beberapa faktor diantaranya keadaan kognitif, afektif dan psikomotornya pada waktu belajar. Kualitas pengajaran yang diterimanya dan cara pengelolaan proses interaksi yang dilakukan oleh guru.

Pakar pendidikan lain mendefinisikan bahwa yang dimaksud hasil belajar adalah perubahan perilaku secara keseluruhan bukan salah satu aspek potensi kemanusiaan saja (Supriyono, 2009:19). Berbeda dengan pendapatnya Bloom (Dalam Sumiati danAska, 2008).Hasil belajar mencakup kemampuan kognitif, afektif, dan psikomotorik. Jadi pendapat ini mengisyaratkan bahwa haasil belajar peserta didik harus diukur dengan tes tertulis, tes sikap, dan kemampuan skil secara nyata selama proses pembelajaran di kelas senyatanya.

Dalam penelitian ini yang dimaksud dengan hasil belajar adalah tes ulangan harian yang dilaksanakan secara tertulis pada akhir pembelajaran.

\section{Pendekatan}

Pendekatan dalam pembelajaran adalah peserta didik/peserta yang aktif.Titik tolak pemikiran bahwa peserta didik diajar dan guru mengajar beralih kepandangan bahwa peserta didik belajar, peserta didik mempelajari beberapa hal yang terus menerus dalam perjalanan hidupnya (Sumiati dan Aska, 2008:8).Dalam praktiknya pendekatan ini selalu disandingkan dengan pembelajaran yang konstektual. Dengan pembelajaran ini peserta didikakan memperolehpengalaman belajar yang mengesankan dan akan diabadikan dalam kehidupan sebagai sosok yang demokratis, berfikir kreatif, yang selalu mengedapkan nilai-nilai kekeluargaan dan kegotongroyongan.

\section{Cooperative Learning (CL) tipe STAD}

STAD merupakan salah satu metode pembelajaran kooperatif yang paling sederhana yang merupakan modul yang paling baik untuk perencanaan bagi para guru yang menggunakan pendekatan cooperative (Robert E. Slavin, 2010:143). Student Teams
Archievent Divisions (STAD) terdiri dari lima komponen utama yaitu: 1) presentasi kelas, 2) Tim, 3) kuis, 4) Skor kemajuan individu, dan 5) Rekognisi Tim.

Presentasi kelas. Materi dalam STAD pertama-tama diperkenalkan dalam presentasi di dalam kelas. Ini merupakan pengajaran langsung seperti yang sering dilakukan atau diskusi pelajaran yang dipimpin oleh guru, tetapi bisa juga memasukkan presentasi audiovisual. Bedanya Presentasi Kelas dengan pengajaran biasa hanyalah bahwa presentasi tersebut haruslah benar-benar berfokus pada unit STAD. Dengan cara ini, para peserta didik akan menyadari bahwa mereka harus benar-benar memberikan perhatian penuh selama presentasi kelas, karena dengan demikian akan sangat membantu mereka mengerjakan kuis-kuias, dan skor kuis mereka menentukan skor tim mereka.

Tim. Tim terdiri dari empat atau lima peserta didik yang mewakili seluruh bagian dari kelas dalam hal kinerja akademik, jenis kelamin, ras dan etnisitas. Fungsi utama dari tim ini adalah memastikan bahwa semua anggota tim benar-benar belajar, dan lebih khususnya lagi, adalah untuk mempersiapkan anggotanya untuk bisa mengerjakan kuis dengan baik. Setelah guru menyampaikan materinya, tim berkumpul untuk mempalajari lembar kegiatan atau materi lainnya. Yang paling sering terjadi, pelajaran itu melibatkan pembahasan permasalah bersama, membandingkan jawaban, dan mengoreksi tiap kesalahan pemahaman apabila anggota tim ada yang membuat kesalahan.

Tim adalah fitur yang paling penting dalam STAD. Pada tiap poinnya, yang ditekankan adalah membuat anggota tim melakukan yang terbaik untuk tim, dan tim pun harus melakukan yang terbaik untuk membantu tiap anggotanya. Tim ini memberikan dukungan kelompok bagi kinerja akademik penting dalam pembelajaran, dan itu adalah untu memberikan perhatian dan respek yang mutual yang penting untuk akibat yang dihasilkan seperti hubungan antarkelompok, rasa harga diri, penerimaan terhadap peserta didik-peserta didikmainstream. 
Kuis. Setelah sekitar satu atau dua periode setelah guru memberikan presentasi dan sekitar satu atau dua periode praktik tim, para peserta didik akan mengerjakan kuis individual. Para iswa tidak diperbolehkan untuk saling membantu dalam mengerjakan kuis. Sehingga, tiap peserta didik bertanggung jawab secara individual untuk memahami materinya.

Skor Kemajuan Individual. Gagasan dibalik skor kenmajuan individual adalah untuk memberikan kepada tiap peserta didik tujuan kinerja yang dapat dicapai apabila mereka bekerja lebih giat dan memberikan kinerja yang lebih baik daripada sebelumnya. Tiap peserta didik dapat memberikan kontribusi poin yang maksimal kepada timnya dalam sistem skor ini, tetapi tidak ada peserta didik yang dapat melakukannya tanpa memberikan usaha mereka yang terbaik. Tiap peserta didik diberikan skor "awal", yang diperoleh dari rata-rata kinerja peserta didik tersebut sebelumnya dalam mengerjakan kuis yang sama. Peserta didik selanjutnya akan mengumpulkan poin untuk tim mereka berdasarkan tingkat kenaikan skor kuis mereka dibandingkan dengan skor awal mereka.

Rekognisi Tim. Tim akan mendapatkan sertifikat atau bentuk penghargaan yang lain apabila skor rata-rata mereka mencapai kriteria tertentu. Skor tim peserta didik dapat juga digunakan untuk menentukan dua puluh persen dari peringkat mereka.

\section{Hipotesis Tindakan.}

Penerapan pendekatan Cooperative Learning $(C L)$ tipe STAD dapat meningkatkan motivasi dan hasil belajar Matematika peserta didik Kelas V SD Negeri 38 Ampenan Semester satu Tahun Pelajaran 2018/2019.

\section{PROSEDUR PENELITIAN}

\section{Setting Penelitian}

Penelitian tindakan kelas (PTK) ini akan dilaksanakan di Kelas V SD Negeri 38 AmpenanSemester satuTahun Pelajaran 2018/2019, dengan jumlah peserta didik sebanyak 27 orang.

\section{Faktor yang Diteliti}

1. Faktor Guru: yaitu dengan mengganti cara guru membuat Rencana Pelaksanaan
Pembelajaran (RPP) dan pelaksanaannya dalam pembelajaran di kelas senyatanya dengan menerapkan pendekatan Cooperatif Learning (CL)tipe STAD dalam upaya meningkatkan motivasi dan hasil belajar Matematika peserta didik Kelas V SD Negeri 38 Ampenan.

2. Faktor Peserta didik: yaitu peningkatan motivasi dan hasil belajarpeserta didik yang terlihat pada perilaku peserta didik selama diskusi kelompok, dan pada saat mengerjakan tes tertulis.

\section{Rencana Tindakan}

kegiatan nyata di Kelas V yaitu melaksanakan proses pembelajaran dengan menerapkan pendekatan Cooperatif Learning $(C L)$ tipe STAD dalam upaya meningkatan motivasi dan hasil belajar Matematika peserta didik kelas V SD Negeri 38 Ampenan Semester satu Tahun Pelajaran 2018/2019. Tindakan nyata yang dilakukan oleh guru selaku peneliti adalah dengan menggunakan siklus.Gambaran siklus dalam penelitian ini adalah sebagai berikut:

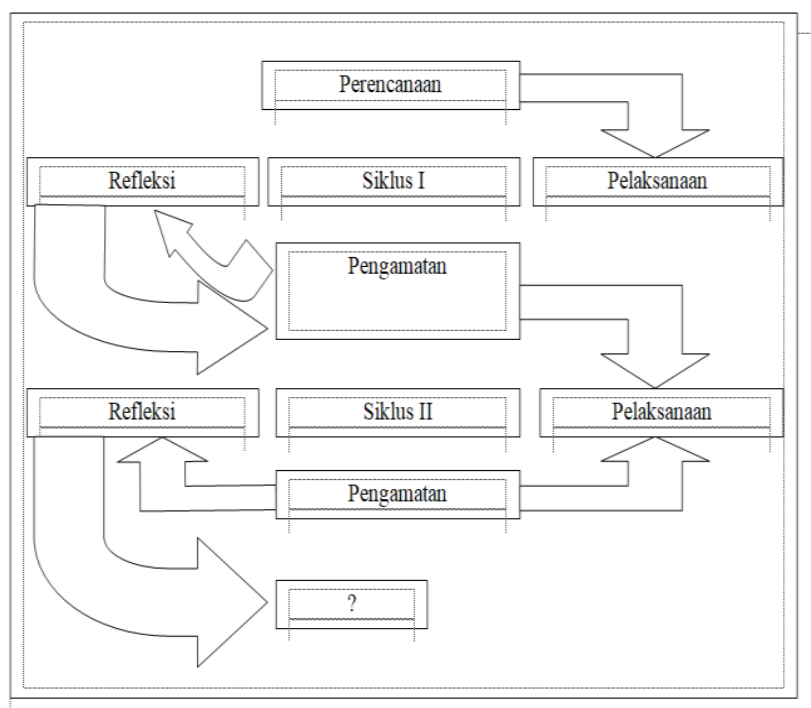

Setiap siklus selama penelitian ini berisi 4 (empat) tahapan yaitu: 1) Perencanaan (Planning), 2) Pelaksanaan (Action), 3) Observasi (Observation), dan 4) Refleksi (Reflection).

\section{Siklus Tindakan \\ SIKLUS I}

\section{Tahap Perencanaan (Planning)}

1. Pada tahapan ini guru selaku peneliti melakukan kegiatan-kegiatan sebagai berikut: 
2. Menyusun Rencana Pelaksanaan Pembelajaran (RPP) dengan skenario sesuai dengan aturan main model pembelajaran Cooperatif learning (CL)tipe STAD.

3. Menyiapkan sumber, bahan, dan semua alat yang digunakan dalam penelitian.

4. Menyusun/membuat lembar observasi guru dan lembar observasi peserta didik.

5. Menyusun alat evaluasi.

Tahap Pelaksanaan (Action)

1. Guru membagi peserta didik menjadi 5 (lima) kelompok kecil, masing-masing kelompok beranggotakan 4-5 orang peserta didik.

2. Masing-masing kelompok diberikan tugas/soal untuk dipecahkan bersama dalam kelompok, selanjutnya melaksanakan 5 (lima) komponen utama STAD yaitu : 1) Presentasi Kelas, 2) Tim, 3) Kuis, 4) Skor kemajuan individual, dan 5) Rekognisi Tim.

\section{Tahap Observasi (Observation)}

1. Observasi guru :Dilakukan oleh pengawas mata pelajaran Matematika observer sekaligus sebagai pembimbing guru dalam melaksanakan Penelitian Tindakan Kelas (PTK).

2. Observasi Peserta didik : Dilaksanakan oleh guru mata pelajaran sekaligus sebagai peneliti dalam Penelitian Tindakan Kelas (PTK) pada kegiatan diskusi kelompok.

4). Tahap Refleksi (Reflection)

1. Renungan hasil perolehan data

2. Pengolahan dan analisa data hasil penelitian

3. Mencocokkan hasil analisa data dengan indikator keberhasilan

4. Rencana perbaikan dan tindak lanjut

SIKLUS II

Pada siklus ini semua kegiatan dan tahapan selama penelitian adalah sama, sifatnya mengulang dan memperbaiki terhadap tindakan yang masih memerlukan penyempurnaan dan pembenaran sebagaimana mestinya.

\section{Data dan Cara Pengambilannya. Sumber Data}

Yang menjadi sumber data dalam penelitian tindakan kelas (PTK) ini adalah semua peserta didikKelas VSemester satuTahun Pelajaran 2018/2019 di SD Negeri 38 Ampenan dan semua tim peneliti.

Jenis Data

- Jenis data yang berasal dari guru selaku peneliti

1). Data tentang Rencana Pelaksanaan Pembelajaran (RPP)

2). Data Pelaksanaan Pembelajaran

- Jenis data yang berasal dari peserta didik :

1). Data kemajuan motivasi dari peserta didik

2). Data hasil belajar peserta didik

\section{Cara Pengambilan data}

- Data kegiatan pembelajaran diambil dari RPP yang dibuat oleh guru dan lembar observasi pelaksanaan model pembelajaran Cooperative Learning (CL) tipe STAD

- Data kemajuan motivasi dan hasil belajar; diambil dari lembar observasi selama diskusi kelompok.

- Data kemajuan hasil belajar; diambil dari nilai pada saat tes tertulis yang dilaksanakan pada akhir proses pembelajaran.

\section{Indikator Keberhasilan dan Teknik analisa} data

\section{Teknik analisa data}

Untuk menganalisis data akan dilakukan melalui analisis deskriptif kuantitatif melalui pendataan, analisis dan pembahasan terhadap data yang diperoleh dengan mencocokkan tingkat keoptimalan terhadap capaian indikator keberhasilan yang ada.

\section{Indikator Keberhasilan}

1. guru telah dinyatakan berhasil melaksanakan proses pembelajaran dengan pendekatan Cooperative Learning $(C L)$ tipe STAD, bila telah mencapai skor rata-rata $\geq 4,00$

2. Motivasi dan hasil belajarMatematikapeserta didikKelas V dinyatakan telah meningkat jika $\geq 85 \%$ dari jumlah peserta didik telah memperoleh skor perolehan skor rata-rata $\geq 4,0$, hasil belajar dinyatakan meningkat jika $\geq 85 \%$ dari jumlah peserta didik memperoleh nilai rata-rata $\geq 75,00$ (Sesuai KKM) 


\section{HASIL PENELITIAN \\ DESKRIPSI SIKLUS I \\ Tahap Perencanaan}

Pada tahapan ini yang telah dilakukan oleh guru selaku peneliti adalah; 1) menyusun RPP dengan skenario pembelajaran CL Tipe STAD, 2) telah berhasil menyiapkan alat, sumber, bahan yang diperlukan dalam penelitian, 3) berhasil menyusun instrument observasi guru dan instrument observasi peserta didik, dan 4) menyusun alat evaluasi.

\section{Tahap Pelaksanaan}

a. Guru membagi peserta didik dalam TIM, yang keanggotaannya secara heterogen dengan harapan dalam satu tim ada yang pintar, sedang dan ada yang kurang. Pembauran agama, ras dan suku agar dalam tim benar-benar heterogen dan berbhineka tunggal ika.

b. Guru menyampaikan materi pelajaran dengan berbagai strategi, kemudian memberikan tugas kepada semua tim untuk dibagikan secara kelompok (mengerjakan kuis)

c. Guru memberikan skor kemajuan individual selama kerja kelompok dalam mengerjakan kuis yang menjadi tanggung jawab tim (kelompok).

d. Rekognisi tim yaitu guru memberikan penghargaan kepada tim atau secara individual apabila hasil kerjanya sudah mencapai criteria yang telah ditetapkan oleh guru.

Selama kerja kelompok dari tahap tim, kuis, skor kemajuan individual, dan rekognisi tim guru melakukan penyeimbangan peningkatan/kemajuan motivasi dan hasil belajarpeserta didik yang meliputi aspek antusias, kerjasama, aktifitas, kemampuan menjawab, dan efektifitas waktu dan hasil tes tertulis.

\section{Tahap Observasi}

Observasi guru memperoleh skor rata-rata sebesar 3,36 dan 3,71, observasi peserta didik memperoleh skor rata-rata sebesar 3,27 dan 3,50. Hasil belajar peserta didik diperoleh dari nilai tugas dan tes tertulis memperoleh nilai rata-rata sebesaar 70,88 dan 61,28

\section{Tahap Refleksi}

1. Renungan data hasil perolehan data pada siklus I
2. Pengolahan data hasil observasi guru, peserta didik dan tes tertulis.

3. Mencocokkan hasil yang ada dengan Indikator keberhasilan.

4. Merencanakan perbaikan terhadap jenis tindakan yang menyebabkan belum tuntas Indikator keberhasilan. Oleh karena Indikator keberhasilan belum terbukti maka penelitian dilanjutkan ke siklus II.

\section{DESKRIPSI SIKLUS II}

\section{Tahap Perencanaan}

Pada tahapan ini jenis kegiatan yang dilakukan masih mengacu pada kegiatan siklus I, bedanya hanya terjadi perbaikan seperlunya yaitu: 1) penyusunan RPP dengan mengacu pada pendekatan CL tipe STAD dan penyempurnaan pada bagian skenario pembelajaran, 2) menyiapkan alat, sumber, bahan yang diperlukan dalam proses tindakan dikelas senyatanyan, 3) menyiapkan lembar observasi guru dan lembar observasi peserta didik sebagaimana pada siklus I, 4) menyiapkan alat evaluasi sebagaimana yang telah dibuat pada siklus I.

\section{Tahap Pelaksanaan}

Secara umum tahapan pelaksanaan proses pembelajaran pada siklus II ini masih mengacu pada pelaksanaan proses pembelajaran sebelumnya. Pemecahan yang dilakukan pada proses pembelajaran ini adalah: 1) pelaksanaan proses diskusi kelompok kecil lebih dioptimalkan, 2) pelaksanaan pembimbingan kelompok sekaligus observasi peserta didik lebih di efektifkan. Utamanya pengamatan peserta didik yang termotivasi, yang kurang motivasi, peserta didik yang tidak termotivasi, dengan harapan proses analisa data lebih signifikan, 3)laporan hasil kerja kelompok yang dibuat secara individu lebih difokuskan, dan 4) pelaksanaan tes tertulis yang merupakan dari peningkatan motivasi dan hasil belajarpeserta didik lebih diperketat.

\section{Tahap Observasi}

Observasi guru memperoleh skor rata-rata sebesar 4,36 dan 4,71, observasi peserta didik memperoleh skor rata-rata sebesar 4,24 dan 4,50. Hasil belajar peserta didik diperoleh dari nilai tugas dan tes tertulis memperoleh nilai rata-rata sebesaar 76,64 dan 81,36 


\section{Tahap Refleksi}

1. Renungan atas perolehan data hasil observasi guru, observasi peserta didik, dan hasil tes tertulis sebagai dampak dari peningkatan motivasi dan hasil belajarpeserta didik di kelas senyatanya.

2. Pengolahan data hasil observasi guru, observasi peserta didik dan tes tertulis

3. Mencocokkan perolehan data hasil tindakan dengan Indikator keberhasilan yang telah ditetapkan.

4. Guru memberikan hadiah/reward kepada semua peserta didik Kelas $\mathrm{V}$ atas keberhasilannya dalam upaya meningkatkan motivasi dan hasil belajar yang berdampak terhadap perolehan hasil belajar sesuai dengan KKM yang telah ditetapkan.

\section{PEMBAHASAN}

\section{SIKLUS I}

\section{Tahap Perencanaan}

Peneliti telah berhasil menyusun RPP dengan skenario penerapan pendekatan Cooperative Learning (CL) tipe STAD, telah berhasilmenyiapkan alat, sumber, bahan yang diperlukan dalam proses pembelajaran, menyusun instrument observasi guru maupun instrument observasi siswa, mengalami sedikit kendala. setelah meminta petunjuk dari pembimbing kendalapun bisa di atasi dengan baik.Dalam penyusunan alat evaluasi, peneliti tidak mengalami hambatan maupun kesulitan.Rumus yang digunakan dalam penentuan keberhasilaan hasil observasi maupun hasil tes tertulis oleh siswa dengan menggunakan rumus deskriptif kualitatif.

\section{Tahap Pelaksanaan}

a. TIM: guru membagi peserta didika menjadi lima tim (kelompok), tiga tim masing-masing beranggotakan 5 (lima) orang peserta didik, dan tiga tim berikutnya beranggotakan masing-masing 4 (empat) orang. Kegiatan selanjutnya guru memberikan materi pelajaran dengan menggunakan berbagai strategi/tipe yang intinya peserta didik bisa menyerap dan memahaminya.

b. Kuis: setelah guru selesai menyampaikan materi pelajaran, setiap peserta didik mengerjakan soal (kuis) secara individu didalam kelompoknya. Para peserta didik tidak boleh bekerjasama satu sama lain, karenanya guru berkeliling untuk mengamati agar peserta didik memiliki tanggung jawab dalam memecahkan soal yang sudah disiapkan oleh guru dalam bentuk lembar kerja peserta didik (LKS).

c. Skor kemajuan individual: pada kegiatan ini guru memberikan apresiasi kepada setiap peserta didik yang bekerja lebih giat serta bekerja lebih baik bila dibandingkan sebelumnya. Bagi peserta didik yang banyak memberikan kontribusi kepada kelompok (tim) diberikan poin sesuai dengan tingkat kebenarannya, begitu seterusnya.

d. Rekognisi tim: tim (kelompok) akan mendapat sertifikat/penghargaan apabila perolehan skor rata-rata mereka mencapai criteria yang telah ditentukan oleh guru Matematika.

Kegiatan pembelajaran diakhiri dengan tes tertulis, hal ini dimaksudkan untuk mengetahui dampak positif dari peningkatan motivasi dan hasil belajar Matematika peserta didik Kelas V SD Negeri 38 Ampenan Semester satu Tahun Pelajaran 2018/2019 dengan penerapan pendekatan cooperative learning $(C L)$ tipe STAD. Asumsi bila motivasi dan hasil belajar meningkat maka akan berdampak meningkatnya hasil belajar peserta didik.

\section{Tahap Observasi}

Observasi guru memperoleh skor ratarata pertemuan I $(3,36)$ pertemuan II $(3,71)$, Hasil observasi peserta didik dalam upaya peningkatan motivasi dan hasil belajar Matematika peserta didik Kelas V Semester satu Tahun Pelajaran 2018/2019 di SD Negeri 38 Ampenan diperoleh skor rataratapertemuan I $(3,27)$ dan pertemuan II $(3,50)$. Dampak dari peningkatan motivasi/belum meningkatnya motivasi dan hasil belajarpeserta didik salah satunya dengan nilai tugas dan hasil tes tertulis yang materinya hanya sekitar yang diajarkan pada saat itu juga, diperoleh nilai rata-rata $(70,88)$ dan $(61,28)$ kategori cukup.

\section{Tahap Refleksi}

Hasil analisa data peningkatan motivasi dan hasil belajar pada siklus I ini $(3,34)$ sedangkan yang diminta dalam Indikator 
keberhasilan $(\geq 4,0)$, ini artinya belum berhasil.

Karena Indikator keberhasilan belum tercapai, penelitian tindakan kelas (PTK) dilanjutkan ke siklus II dengan harapan optimalisasi penerapan strategi pembelajaran dengan pendekatan CL tipe STAD dapat meningkatkan motivasi dan hasil belajar Matematika peserta didik Kelas V Semester satuTahun Pelajaran 2018/2019 di SD Negeri 38 Ampenan.

\section{SIKLUS II}

\section{Tahap Perencanaan}

Peneliti menyusun Rencana Pelaksanaan Pembelajaran (RPP) dengan memperhatikan kesalahan-kesalahan pada siklus I. peneliti lebih memfokuskan tentang Rencana strategi jitu sehingga proses pembelajaran dengan pendekatan cooperative learning (CL) tipe STAD dapat terelaisasi dengan baik, karenanya dalam penyusunan skenario benar-benar dirinci dari tiap aspek pada proses pembelajaran dengan STAD.

Sebelum proses pembelajaran dilaksanakan, peneliti menyiapkan semua alat, bahan, dan segala sesuatunya sehingga dalam pelaksanaan proses pembelajaran berjalan sesuai dengan skenario yang telah direncanakan. Agar proses pembelajaran dapat teratasi maka peneliti juga menyiapkan lembar observasi guru dan lembar observasi peserta didik sebagai tolak ukur ketercapaian peningkatan motivasi dan hasil belajar Matematika peserta didik Kelas V SD Negeri 38 Ampenan.

\section{Tahap Pelaksanaan}

Pada tahap pelaksanaan di siklus II ini pada dasarnya masih mengacu pada pelaksanaan siklus I, yaitu penerapan pendekatan cooperative learning $(C L)$ tipe STAD. Bedanya pada siklus ini lebih dioptimalkan.

\section{Tahap Observasi}

Pada siklus II ini hasil observasi memperoleh skor rata-rata pertemuan I $(4,36)$ dan pertemuan II $(4,71)$, Upaya meningkatkan motivasi dan hasil belajar Matematika peserta didik Kelas V Semester satuTahun Pelajaran 2018/2019 di SD Negeri 38 Ampenan diperoleh skor rata-rata pertemuan I $(4,24)$ dan pertemuan II $(4,50)$, Sebagai tolak ukur keberhasilan proses pembelajaran adalah hasil belajar peserta didik meningkat, dari data nilai tugas dan hasil perolehan nilai rata-rata tes tertulis adalah $(76,64)$ dan $(81,36)$ ini berarti mengalami peningkatan yang signifikan.

\section{Tahap Refleksi}

Hasil analisa data peningkatan motivasi dan hasil belajarpeserta didik pada siklus II adalah $(4,37)$ sedangkan Indikator keberhasilan $(\geq 4,0)$. Ini artinya pada siklus II hasilnya telah melampaui Indikator keberhasilan, sedangkan hasil belajar rata-rata 79,00 dari indikator keberhasilan $\geq 75,00$, artinya telah melampaui indikator keberhasilan yang ditentukan.

Karena Indikator keberhasilan telah terbukti, maka tidak perlu ada upaya perbaikan dan penyempurnaan. Pendekatan cooperative learning $(C L)$ tipe STAD telah mampu meningkatkan motivasi dan hasil belajar peserta didik yang ditandai dengan tercapainya Indikator keberhasilan dan terjadinya peningkatan hasil belajar peserta didik. "Penelitian Tindakan Kelas (PTK) dihentikan pada siklus II dengan hasil memuaskan."

\section{SIMPULAN}

Data komulatif dari hasil penelitian tindakan kelas (PTK) dari siklus I ke Siklus II adalah sebagai berikut:

\begin{tabular}{|l|l|c|c|c|c|c|}
\hline No & Jenis Kegiatan & $\begin{array}{c}\text { Indikator } \\
\text { keberhasilan }\end{array}$ & Pertemuan & Siklus I & Siklus II & Keterangan \\
\hline \multirow{2}{*}{ 1. } & \multirow{2}{*}{ Observasi Guru } & $\geq 4,00$ & I & 3,36 & 4,36 & Tuntas \\
\cline { 3 - 7 } & $\geq 4,00$ & II & 3,71 & 4,71 & Tuntas \\
\hline \multirow{2}{*}{ 2. } & $\begin{array}{l}\text { Observasi Peserta } \\
\text { didik }\end{array}$ & $\geq 4,00$ & I & 3,27 & 4,24 & Tuntas \\
\cline { 2 - 7 } & $\geq 4,00$ & II & 3,50 & 4,50 & Tuntas \\
\hline \multirow{2}{*}{ 3. } & Nilai Tugas & $\geq 75,00$ & & 70,88 & 76,64 & Tuntas \\
\hline 4. & Nilai Tes Tertulis & $\geq 75,00$ & & 61,28 & 81,36 & Tuntas \\
\hline
\end{tabular}

Penerapan pendekatan cooperative learning (CL) tipe Student Teams Archivement Division (STAD) sangat efektif upaya untuk meningkatkan motivasi dan hasil belajar Matematika peserta didik Kelas V Semester satu Tahun Pelajaran 2018/2019 di SD Negeri 38 Ampenan. Fakta telah menunjukkan perolehan rata-rata skor motivasi dan hasil belajarpeserta didik pada siklus I $(3,39)$, sedangkan pada siklus II $(4,37)$, hasil belajar siklus I $(66,08)$ dan Siklus II $(79,00)$ sudah melampaui Indikator 
keberhasilan yang ditetapkan. Penelitian dinyatakan "berhasil" dan dihentikan pada siklus II.

SARAN

Disarankan kepada guru sejawat untuk melaksanakan Penelitian Tindakan Kelas (PTK) dalam upaya untuk meningkatkan motivasi dan atau hasil belajar peserta didik sesuai dengan mata pelajaran masing-masing.

Disarankan kepada para semua peserta didik Kelas VII SD Negeri 38 Ampenan untuk membiasakan belajar dengan pendekatan yang kontekstual utamanya strategi yang mampu membangkitkan motivasi dan hasil belajarpeserta didik yang dampaknya hasil belajar dapat ditingkatkan seperti yang diharapkan.

\section{DAFTAR PUSTAKA}

Arikunto, s. 2009, Penelitian Tindakan Kelas, Jakarta : Bumi Aksara.

Harun Rasyid dan Mansur, 2008, Penilaian Hasil Belajar, Bandung : CV Wacana Prima.

Lukmanul A, 2008, Perencanaan Pembelajaran, Bandung : CV Wacana Prima.

Mukhtar, 2003, Prosedur Penilaian, Jakarta : Rineka Cipta.

Nurhadi, 2003, Yasin ,B dan Sendule.A, 2003, Kontekstual dan Penerapannya dalam KBK, Malang : Unitipetas Negeri Malang.

Robert E Slavin, 2010, Cooperative Learning Teori, riset dan Praktik, Bandung : Nusa Media.

Sardiman, 2007, Indikator Dan Motivasi dan hasil belajar Mengajar, Jakarta : Raja Grafindo Perkasa.

Supriono, 2009, Cooperative Learning Teori dan Aplikasi PAIKEM, Yogyakarta : Pustaka Pelajar.

Syahrir, S., \& Susilawati, S. (2015). Pengembangan Modul Pembelajaran Matematika Siswa SMP. Jurnal Ilmiah Mandala Education (JIME), 1(2), 162171. 